Article

\title{
Activity-Dependent Neuroprotective Protein (ADNP)-Derived Peptide (NAP) Counteracts UV-B Radiation-Induced ROS Formation in Corneal Epithelium
}

Grazia Maugeri 1,+ (D), Agata Grazia D’Amico ${ }^{2,+}$, Salvatore Giunta ${ }^{1}\left(\mathbb{D}\right.$, Cesarina Giallongo ${ }^{3}$, Daniele Tibullo 4 (D) Claudio Bucolo ${ }^{5,6}$, Salvatore Saccone ${ }^{7}$ D , Concetta Federico ${ }^{7}$, , Davide Scollo ${ }^{8}$, Antonio Longo ${ }^{6,8}$, Teresio Avitabile 6,8, Giuseppe Musumeci ${ }^{1}$ (D) and Velia D'Agata ${ }^{1, *(D)}$

check for updates

Citation: Maugeri, G.; D'Amico, A.G.; Giunta, S.; Giallongo, C.;

Tibullo, D.; Bucolo, C.; Saccone, S.;

Federico, C.; Scollo, D.; Longo, A.;

et al. Activity-Dependent

Neuroprotective Protein

(ADNP)-Derived Peptide (NAP)

Counteracts UV-B Radiation-Induced

ROS Formation in Corneal

Epithelium. Antioxidants 2022, 11, 128.

https://doi.org/10.3390/

antiox11010128

Academic Editor: Ram Kannan

Received: 22 December 2021

Accepted: 5 January 2022

Published: 7 January 2022

Publisher's Note: MDPI stays neutral with regard to jurisdictional claims in published maps and institutional affiliations.

Copyright: (C) 2022 by the authors. Licensee MDPI, Basel, Switzerland. This article is an open access article distributed under the terms and conditions of the Creative Commons Attribution (CC BY) license (https:// creativecommons.org/licenses/by/ $4.0 /)$.
1 Section of Anatomy, Histology and Movement Sciences, Department of Biomedical and Biotechnological Sciences, University of Catania, 95100 Catania, Italy; graziamaugeri@unict.it (G.M.); sgiunta@unict.it (S.G.); g.musumeci@unict.it (G.M.)

2 Department of Drug Sciences, University of Catania, 95125 Catania, Italy; agata.damico@unict.it

3 Department of Medical, Surgical Sciences and Advanced Technologies G.F. Ingrassia, University of Catania, 95123 Catania, Italy; cesarina.giallongo@unict.it

4 Department of Biomedical and Biotechnological Sciences, Section of Biochemistry, University of Catania, 95123 Catania, Italy; d.tibullo@unict.it

5 Pharmacology Section, Department of Biomedical and Biotechnological Sciences, University of Catania, 95123 Catania, Italy; claudio.bucolo@unict.it

6 Center for Research in Ocular Pharmacology (CERFO), University of Catania, 95123 Catania, Italy; antlongo@unict.it (A.L.); t.avitabile@unict.it (T.A.)

7 Section of Animal Biology, Department of Biological, Geological and Environmental Sciences, University of Catania, 95123 Catania, Italy; saccosal@unict.it (S.S.); federico@unict.it (C.F.)

8 Department of Ophthalmology, Eye Clinic, University of Catania, 95123 Catania, Italy; davidescollo@hotmail.com

* Correspondence: vdagata@unict.it; Tel.: +39-095-3782147

+ These authors contributed equally to this work.

\begin{abstract}
The corneal epithelium, the outermost layer of the cornea, acts as a dynamic barrier preventing access to harmful agents into the intraocular space. It is subjected daily to different insults, and ultraviolet B (UV-B) irradiation represents one of the main causes of injury. In our previous study, we demonstrated the beneficial effects of pituitary adenylate cyclase-activating polypeptide (PACAP) against UV-B radiation damage in the human corneal endothelium. Some of its effects are mediated through the activation of the intracellular factor, known as the activity-dependent protein $(\mathrm{ADNP})$. In the present paper, we have investigated the role of ADNP and the small peptide derived from ADNP, known as NAP, in the corneal epithelium. Here, we have demonstrated, for the first time, ADNP expression in human and rabbit corneal epithelium as well as its protective effect by treating the corneal epithelial cells exposed to UV-B radiations with NAP. Our results showed that NAP treatment prevents ROS formation by reducing UV-B-irradiation-induced apoptotic cell death and JNK signalling pathway activation. Further investigations are needed to deeply investigate the possible therapeutic use of NAP to counteract corneal UV-B damage.
\end{abstract}

Keywords: corneal epithelium; UV-B; ADNP; NAP; ROS; apoptosis

\section{Introduction}

The cornea is a transparent and highly specialized tissue forming, along with the conjunctiva, the ocular surface. It protects the eye against different insults and provides two-thirds of the total refractive power of the eye [1]. The cornea comprises five different layers: The epithelium, Bowman's membrane, the stroma, Descemet's membrane, and the endothelium. The corneal epithelium acts as a dynamic barrier preventing the access of harmful agents to the intraocular space. It is a non-keratinized stratified squamous 
epithelium, constituted by 5-7 layers of cells forming a smooth uniform surface. The inner basal layer is characterized by a monolayer of columnar cells implicated in the generation of new suprabasal cells. Moreover, these cells secrete matrix factors essential for basement membrane and stromal function. The integrity of the cornea is dependent upon the self-renewing properties of limbal epithelial stem cells situated in crypts along the cornea-scleral border [2]. The cornea is subjected to different intrinsic and extrinsic insults, such as ultraviolet B (UV-B) irradiation, representing one of the most common corneal injuries. The cornea absorbs approximately $80 \%$ of UV-B rays, and prolonged exposure to this insult might provoke edema, photokeratitis, and photo-ophthalmia. The UV-B rays alter the corneal epithelium thickness and induce corneal endothelium damage causing fluctuating or occasionally blurred vision $[3,4]$. The UV-B irradiation drastically increases reactive oxygen species (ROS) levels, leading to apoptotic cell death [5,6]. More specifically, ROS produced by UV-B light act as second messengers to activate diverse redox-sensitive signalling transduction cascades, including the stress-activated MAP kinases p38 and the Jun-N Terminal kinase (JNK) [7]. The adverse effects of UV-B radiation can be reduced by the use of sunscreens, although total protection against this insult cannot be guaranteed. Damage to the corneal epithelium can result in pain, inflammation, vascularization, and in the worst-case, blindness. Based on the severity of the damage, keratoplasty may be needed. Therefore, the identification of molecules exerting a protective effect against UV-B-induced corneal damage might represent an effective alternative to the surgical approach. In our previous study, we demonstrated the beneficial effects of pituitary adenylate cyclase-activating polypeptide (PACAP) against UV-B radiation damage in human corneal endothelial cells [8]. PACAP is a well-established cytoprotective peptide, largely distributed in the central nervous system and in several peripheral organs $[9,10]$. It plays different functions through the activation of three distinct G-protein-coupled receptors: PAC1R, VPAC1R, and VPAC2R [11]. PACAP is involved in different biological processes such as cell division and survival [12-14] as well as exerting a protective role in neurodegenerative diseases [15-20].

Some PACAP effects are also mediated by the stimulation of an intracellular factor, known as the activity-dependent protein (ADNP) [21,22]. In 1999, Bassan et al. [21] synthesized a small peptide of eight amino acids derived from ADNP, known as NAP (davunetide, NAPVSIPQ/Asn-Ala-Pro-Val-Ser-Ile-Pro-Gln) acting as a protective agent in cerebral ischemia, severe head injury, and retinal damage induced by different insults [21-27]. It also exhibits metal chelating, antioxidant, and anti-inflammatory properties [28-32].

To date, the role of ADNP in corneal epithelium has not been investigated yet. Here we have demonstrated, for the first time, its expression in this tissue as well as the exogenous effect of ADNP mimicking peptide, NAP, on corneal epithelial cells exposed to UV-B radiations. Our results showed that NAP treatment reduces UV-B-irradiation-induced ROS formation, decreases JNK pathway activation, and consequently reduces apoptotic events. Further investigations are needed to determine the possible therapeutic use of NAP to counteract corneal UV-B damage.

\section{Materials and Methods}

\subsection{Ethics Statement}

This study was carried out according to the tenets of the Declaration of Helsinki. The human sclerocorneal button stored in organ culture at $31^{\circ} \mathrm{C}$ were supplied for penetrating keratoplasty by the Eye Bank (Fondazione Banca degli Occhi del Veneto; Venezia-Mestre, Italy), which obtained informed consent for all tissue samples held and cultured (Ethical approval number 99/2019/PO). 


\subsection{Animals}

All animal studies were in accordance with the Association for Research in Vision and Ophthalmology (ARVO) Statement for the Use of Animals in Ophthalmic and Vision Research. The animal protocols were reviewed and approved by the Institution of Animal Care and Use Committee of Catania University (Approval number 303). Male New Zealand albino rabbits $(2.0-2.5 \mathrm{Kg} ; n=7)$ were purchased from Envigo (Udine, Italy). The rabbits were housed under standard conditions. They were provided with food and water and maintained at a temperature and relative humidity of $21 \pm 3{ }^{\circ} \mathrm{C}$ and $54 \pm 4 \%$, respectively. The lighting was artificial with a $12 \mathrm{~h}$ light/dark cycle, with lights switched on at $6 \mathrm{am}$. All animals were healthy and without ocular alterations.

\subsection{Histological Analysis}

Human and rabbit cornea were collected and fixed in 10\% buffered formalin for $2 \mathrm{~h}$. The specimens were washed overnight, dehydrated in graded ethanol, and paraffin embedded. The histological analysis was performed on $5 \mu \mathrm{m}$ sections obtained using a rotary manual microtome (Leica RM2235, Milan, Italy). Cellular and tissue structure were viewed by staining the sections with H\&E. The sections were examined using a Zeiss Axioplan light microscope (Carl Zeiss, Oberkochen, Germany) and the pictures were acquired with a digital camera (AxioCam MRc5, Carl Zeiss, Oberkochen, Germany).

\subsection{Immunohistochemistry (IHC) Analysis}

The expression and distribution of ADNP and p-63 in human and rabbit corneas was evaluated through immunohistochemical analysis [33]. The specimens were dewaxed in xylene, hydrated in graded ethanol and then incubated for $0.3 \% \mathrm{H}_{2} \mathrm{O}_{2} /$ methanol ( $30 \mathrm{~min}$ ) to eliminate endogenous peroxidase activity. The sections were placed in a thermoregulated bath $\left(80^{\circ}\right.$ for $\left.30 \mathrm{~min}\right)$ with a rodent decloaker (Biocare Medical, Pacheco, CA, USA) to perform antigen retrieval. To reduce the non-specific binding of the antibody, the sections were blocked with $1 \%$ bovine serum albumin (BSA, Sigma, Milan, Italy) in PBS for $1 \mathrm{~h}$, then the sections were incubated overnight at $4{ }^{\circ} \mathrm{C}$ with ADNP antibody (NBP1-89236; Novus Biologicals, Milan, Italy; 1:50) or rabbit p63 antibody (ab124762; Abcam, Cambridge, UK; 1:1000) work dilution in PBS and 1\% BSA. The sections were incubated with secondary antibodies conjugated to polymer-HRP (LSAB+ System-HRP, K0690, Dako, Denmark), and the immunoreaction was detected by incubating them for $3 \mathrm{~min}$ in a 3,3'-diaminobenzidine solution (DAB substrate Kit; SK-4100, Vector Laboratories, Burlingame, CA, USA). The samples were lightly counterstained with hematoxylin, mounted in a vecta mount (Vector Laboratories) and observed with an Axioplan Zeiss light microscope (Carl Zeiss), and photographed with a digital camera (AxioCam MRc5, Carl Zeiss).

\subsection{Cell Cultures}

Statens Seruminstitut rabbit corneal (SIRC) epithelial cells (ATCC CCL-60) were grown in Eagle's Minimum Essential Medium (ATCC ${ }^{\circledR}$ 30-2003TM) supplemented with 10\% fetal bovine serum (FBS, 10108-165, GIBCO, Milan, Italy) at $37^{\circ} \mathrm{C}$. The culture medium was exchanged every other day, and cultures were maintained until sub-confluence was reached. Cells were exposed to $30 \mathrm{~s}$ UV-B radiation at a dose of $20 \mathrm{~mJ} / \mathrm{cm}^{2}$ using UVllink CL-508M (UVItec, Cambridge, UK).

\subsection{Immunofluorescence Analysis}

To determine the cellular distribution of the ADNP protein, immunofluorescence analysis was performed on SIRC cells as previously described by Maugeri et al. [34]. Cells cultured on glass coverslips were fixed in 4\% paraformaldehyde in PBS for $15 \mathrm{~min}$ at room temperature, permeabilized with $0.2 \%$ Triton X-100, blocked with $0.1 \%$ BSA in PBS, and then probed with the rabbit anti-ADNP (NBP1-89236; Novus Biologicals; $1 \mu \mathrm{g} / \mathrm{mL}$ ) antibody. Signals were revealed with Alexa Fluor 488 goat anti-rabbit, for $1.5 \mathrm{~h}$ at room temperature (shielded from light). DNA was counterstained with 4,6-diamidino-2-phenylindole (DAPI; 
cat. no 940110; Vector Laboratories, Burlingame, CA, USA). After a series of washes in PBS and double-distilled water, the fixed cells were cover-slipped with the Vectashield mounting medium (Vector Laboratories). Immunolocalization was analyzed by confocal laser scanning microscopy (Zeiss LSM700, Oberkochen, Germany) at $40 \times$.

\subsection{Cell Viability Assay}

Cell viability was determined by 3-[4,5-dimethylthiazol-2-y 1]-2,5-diphenyl tetrasodium bromide (MTT assay, cell proliferation kit, catalog number: 11465007001, Roche Diagnostics, Indianapolis, IN, USA). Cells were seeded into 96-well plates at a density of $1 \times 10^{4}$ cells/well in $100 \mu \mathrm{L}$ of the culture medium for 1 day [35]. After overnight growth, SIRC cells were grown in the different experimental conditions, and at the end of treatment, $0.5 \mathrm{mg} / \mathrm{mL}$ of MTT was added to each well and incubated for $4 \mathrm{~h}$ at $37^{\circ} \mathrm{C}$. The reaction was stopped by adding $100 \mu \mathrm{L}$ of the solubilization solution, then formazan formed by the cleavage of the yellow tetrazolium salt MTT was measured spectrophotometrically by an absorbance change at $570 \mathrm{~nm}$ in a plate reader (VariosKan, Thermo Fisher Scientific, Waltham, MA, USA). Twelve replicate wells were used for each group. The medium alone was used as a blank.

\subsection{Fluorescence Microscopic Analysis of Cell Death}

Cells were seeded into 12-well plates at a density of $4 \times 10^{3}$ cells/well in $500 \mu \mathrm{L}$ of the culture medium. After $24 \mathrm{~h}$, cells were incubated in the control medium (CTRL), or in the presence of $10 \mathrm{nM}$ NAP, or exposed to ultraviolet irradiation (UV-B) for $30 \mathrm{~s}$ with or without NAP for $24 \mathrm{~h}$. Cells were incubated with a solution of methanol/acetic acid (3:1 v/v) for $30 \mathrm{~min}$, rinsed three times in PBS, and incubated with Hoechst 33,342 dye $(0.4 \mu \mathrm{g} / \mathrm{mL})$. When all the necessary washing steps were completed, cells were visualized using the Axiovert 40 fluorescence microscope (Carl Zeiss, Oberkochen, Germany) as previously described by Maugeri et al. [36]. Apoptotic cells were recognized on the basis of nuclear condensation and/or fragmented chromatin. Each condition was reproduced in three dishes per experiment. Both apoptotic and normal cells were counted from three fields per dish in a fixed pattern. The apoptotic nuclei counting was carried out independently by two investigators, and wherever disagreement arose, a third investigator was called upon to verify the results.

\subsection{Detection of ROS}

ROS was measured by means of the $2^{\prime}, 7^{\prime}$-dichlorofluorescin diacetate (DCFDA)Cellular Reactive Oxygen Species Detection Assay Kit (ab113851, Abcam, Cambridge, UK), according to the manufacturer's protocol. SIRC cells were plated into 96-well black plates at a density of $1 \times 10^{4}$ cells / well for $24 \mathrm{~h}$. After overnight growth, SIRC cells were grown in the control medium (CTRL), or in the presence of $10 \mathrm{nM}$ NAP, or exposed to ultraviolet irradiation (UV-B) for $30 \mathrm{~s}$ with or without NAP for $24 \mathrm{~h}$. Cells were washed gently in PBS twice and incubated with $25 \mu \mathrm{M}$ DCFDA previously dissolved in a buffer solution for $45 \mathrm{~min}$ in the dark. The determination of the ROS concentration was performed by measuring the DCF fluorescence $(\lambda e x=495 \mathrm{~nm}, \lambda e m=529 \mathrm{~nm})$ with VarioskanTM. Twelve replicate wells were used for each group.

Mitochondrial-derived ROS (mtROS) detection was performed using the MitoSOX ${ }^{\mathrm{TM}}$ Red mitochondrial superoxide indicator (ThermoFisher Scientific, Milano, Italy). Cells were stained using $3 \mu \mathrm{M}$ of the MitoSOX ${ }^{\mathrm{TM}}$ Red mitochondrial superoxide indicator (ThermoFisher Scientific, Milano, Italy). After incubation for $10 \mathrm{~min}$ at $37^{\circ} \mathrm{C}$, cells were washed three times and analyzed by MACSQuant Analyzer 10 (Miltenyi Biotec, Bologna, Italy).

\subsection{Western Blot Analysis}

Western blot analysis was performed according to the procedures previously described [37]. Proteins were extracted with buffer containing $20 \mathrm{mM}$ Tris (pH 7.4), $2 \mathrm{mM}$ EDTA, $0.5 \mathrm{mM}$ egtazic acid, $50 \mathrm{mM}$ mercaptoethanol, $0.32 \mathrm{mM}$ sucrose, and a protease 
inhibitor cocktail (Roche Diagnostics, Monza, Italy) using a Teflon-glass homogenizer and then sonicated twice for $20 \mathrm{~s}$ using an ultrasonic probe, followed by centrifugation at $10,000 \times g$ for $10 \mathrm{~min}$ at $4{ }^{\circ} \mathrm{C}$. Protein concentrations were determined by the Quant-iT Protein Assay Kit (Invitrogen, Carlsbad, CA, USA). About $20 \mu \mathrm{g}$ of protein homogenate were diluted in $2 \times$ Laemmli buffer (Invitrogen), heated at $70{ }^{\circ} \mathrm{C}$ for $10 \mathrm{~min}$, and then separated on a Biorad Criterion XT (Hercules, CA, USA) 4\% to 15\% bis-tris gel (Invitrogen) by electrophoresis and then transferred to a nitrocellulose membrane (Invitrogen). Blots were blocked using the Odyssey Blocking Buffer (Li-Cor Biosciences, Nebraska, NE, USA). The transfer was monitored by a prestained protein molecular weight marker (BioRad Laboratories, Milan, Italy). Immunoblot analysis was performed by using appropriate antibodies: Rabbit anti-ADNP (NBP1-89236; Novus Biologicals; 1:50); mouse anti-Bcl2 (sc-509, Santa Cruz Biotechnology, Dallas, TX, USA; 1:200); mouse anti-Bax (sc-20067, Santa Cruz Biotechnology; 1:200); rabbit anti-JNK (sc-571; Santa Cruz Biotechnology, 1:200); mouse anti-p-JNK (sc-6254; Santa Cruz Biotechnology, Texas City, TX, USA; 1:200); and rabbit anti- $\beta$-tubulin (cat n.sc-9104, Santa Cruz Biotechnology; 1:500). The secondary antibodies goat anti-rabbit IRDye 800CW (926-32211; Li-Cor Biosciences) and goat anti-mouse IRDye 680CW (92668020D; Li-Cor Biosciences, Nebraska, USA) were used at 1:15,000 and 1:20,000, respectively. Blots were scanned with an Odyssey Infrared Imaging System (Odyssey, Li-Cor Biosciences, Nebraska, USA). Densitometric analyses of Western blot signals were performed at nonsaturating exposures and analyzed using ImageJ software (National Institutes of Health, Bethesda, Maryland, USA; available at: http:/ / rsb.info.nih.gov/ij/index.html, accessed on 12 November 2021). Values were normalized to $\beta$-tubulin, which served as a loading control.

\subsection{Statistical Analysis}

Data are represented as mean \pm SEM. One-way analysis of variance was used to compare differences among groups, and statistical significance was assessed by the TukeyKramer post-hoc test. The level of significance for all statistical tests was set at $p \leq 0.05$.

\section{Results}

\subsection{ADNP Expression in Human and Rabbit Corneal Epithelium}

The detection of ADNP expression in human and rabbit corneal epithelium was performed using IHC analysis. As shown in Figure 1, H\&E staining of humans' and rabbits' cornea sections showed comparable architecture overall. In humans as well as in rabbits, ADNP was expressed in all examined epithelial layers, although higher staining intensity was observed in cells laying on the contact area of the basement membrane (Figure 1A,B). To identify the cellular phenotype mainly expressing the peptide, we also analyzed the distribution of the corneal epithelial stem cell marker p63. As shown in Figure 1B, ADNP was mainly expressed in the basal layer containing a large number of p63-positive cells [38].

To investigate whether ADNP expression is affected by UV-B irradiation, we analyzed the expression levels of this protein in rabbit corneal epithelial cells following exposure to UV-B insult. As shown in Figure 2A, the expression levels of ADNP were significantly induced by UV-B radiation compared to the control as measured by Western blot analysis (*** $p<0.001$ vs. CTRL). To establish ADNP subcellular localization, immunofluorescence analysis was performed. As depicted in Figure 2B, ADNP was detected in the cytoplasm of controls. Interestingly, in SIRC cells following UV-B exposure, ADNP was revealed not only in the cytoplasm but also in the nucleus by forming small subnuclear bodies. This result suggested that UV-B radiation induced the translocation of the protein from the cytoplasm to nucleus. In accord, at the single cell level, ADNP was found both in the nucleus and in the cytoplasm, and the ADNP cytoplasm-nucleus translocation was already observed by Dr. Gozes' group [39]. 
$\mathbf{A}$
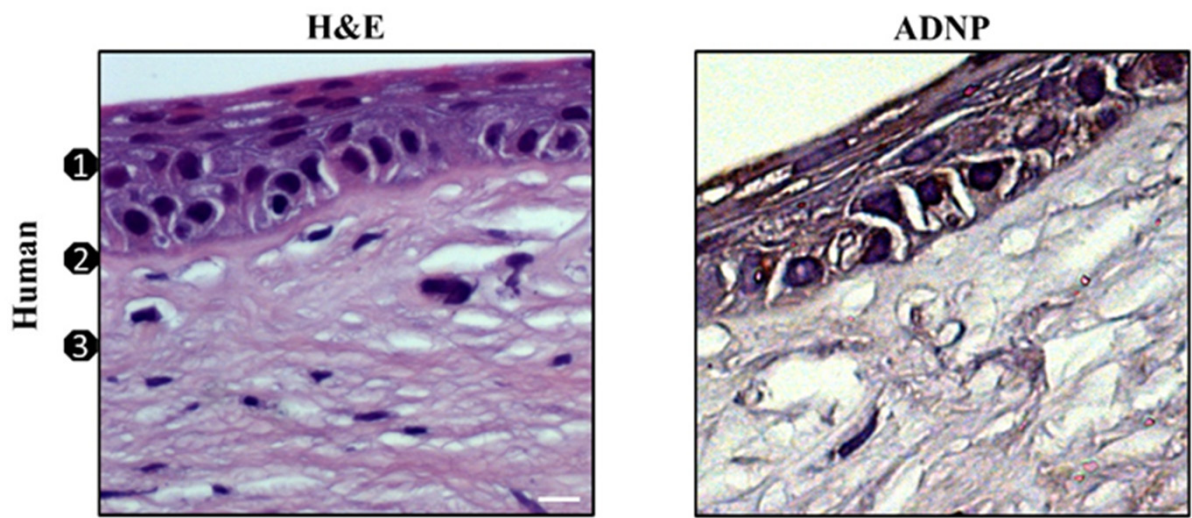

B

H\&E

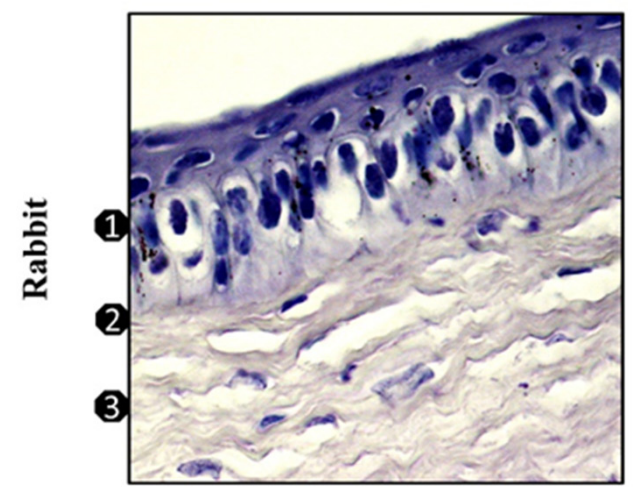

ADNP

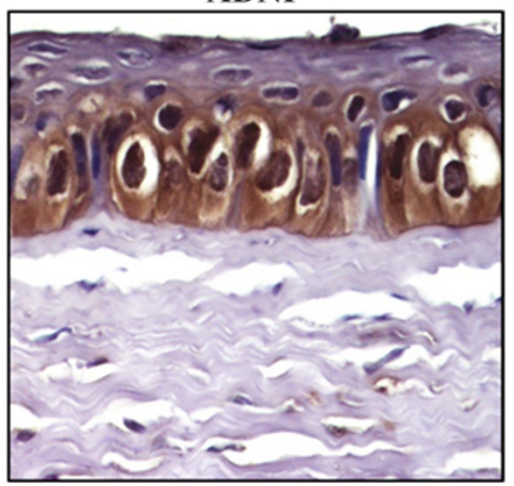

P63

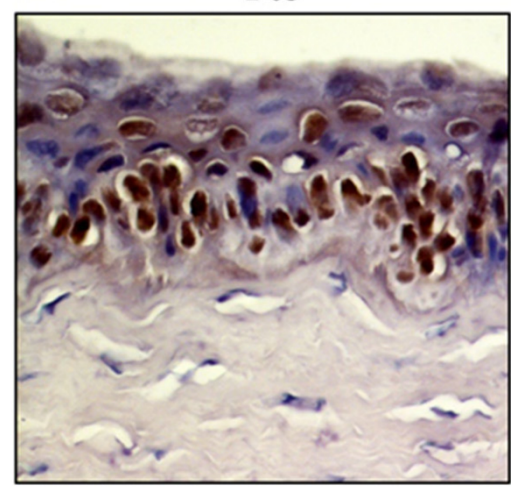

Figure 1. Expression of ADNP and p63 in corneal epithelium. H\&E staining and immunodetection of ADNP and p63 in human (A) and rabbit (B) cornea: (1) Epithelium, (2) Bowman's membrane, (3) stroma. Original magnification $\times 200$. Digital micrographs are representative results of fields taken in randomly selected slides and obtained using the Zeiss Axioplan light microscope (Carl Zeiss) fitted with a digital camera (AxioCam MRc5; Carl Zeiss); scale bar: $20 \mu \mathrm{m}$.

\subsection{NAP Treatment Reduced UVB-Irradiation-Induced Apoptosis on Corneal Epithelial Cells}

Acute UV-B exposure provokes damage in the cornea by inducing apoptotic cell death $[40,41]$. To investigate the role of ADNP on corneal epithelium, we tested the effect of NAP, a small peptide mimicking the ADNP effect, in a model in vitro of corneal epithelial cells exposed to this insult. To choose the most suitable time point to test the protective action of the peptide, we performed a cell-viability time-response curve by exposing SIRC cells to $30 \mathrm{~s}$ UV-B-irradiation $\left(20 \mathrm{~mJ} / \mathrm{cm}^{2}\right)$. As shown in Figure 3A, cell viability was significantly reduced in a time-dependent manner starting from $24 \mathrm{~h}$ following UV-B insult (**** $p<0.0001$ vs. CTRL). Therefore, we selected this time point to perform the other experiments. In order to choose the minimum effective dose of NAP able to counteract the UV-B-irradiation-damage, we performed a dose-response analysis by treating cells with various NAP concentrations for $24 \mathrm{~h}$. As shown in Figure 3B, $10 \mathrm{nM}$ of NAP concentration significantly increased cell viability as compared to the UV-B group (\#\#\# $p<0.0001$ vs. UV-B).

Then, we assessed the effect of NAP to prevent the apoptotic death of cells exposed to UV-B by using Hoechst 33342 staining. As shown in Figure 4, nuclei apoptotic degeneration, represented by an intense blue fluorescence due to the chromatin condensation and fragmentation, was mainly observed in the UV-B exposed group as compared to the control. The treatment of UV-B-exposed cells with NAP significantly reduced the percentage of apoptotic nuclei. 
A
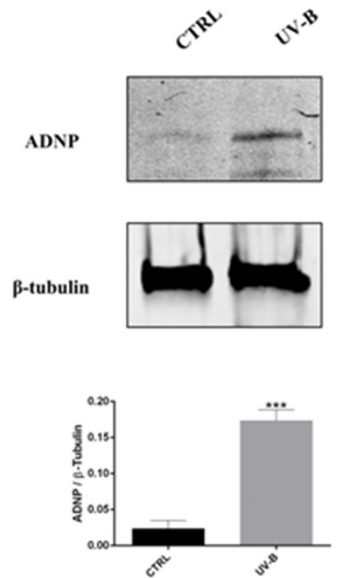

B

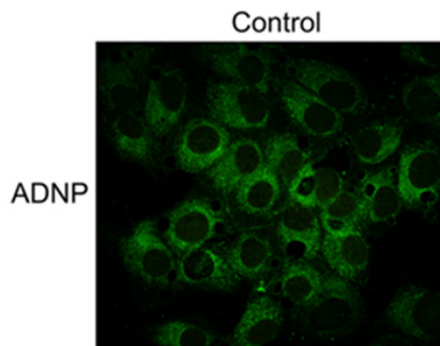

$50 \mathrm{kDa}$

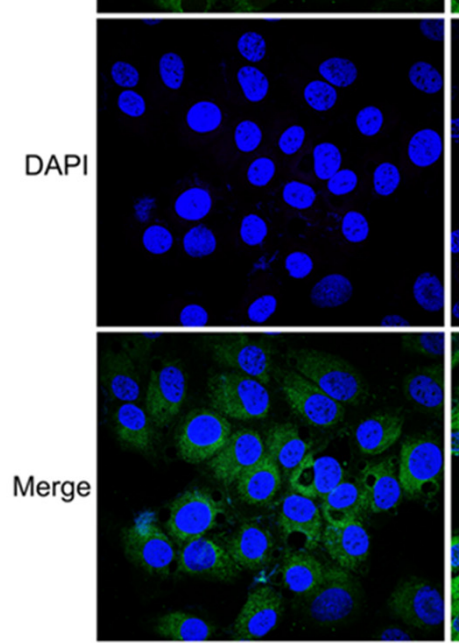

UV-B
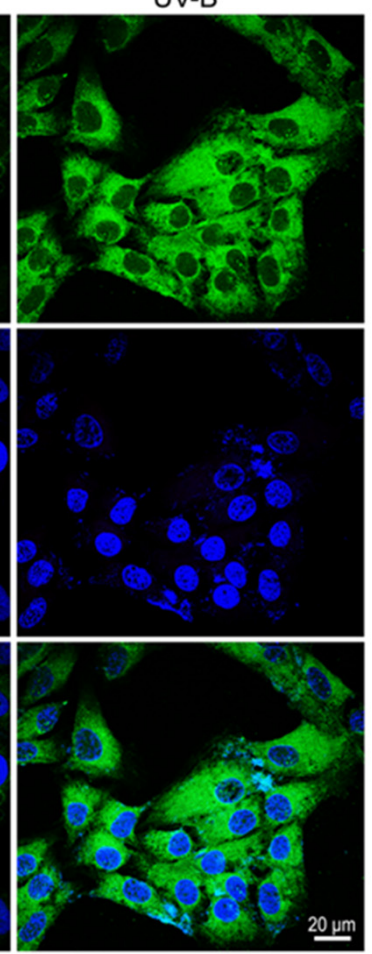

UV-B

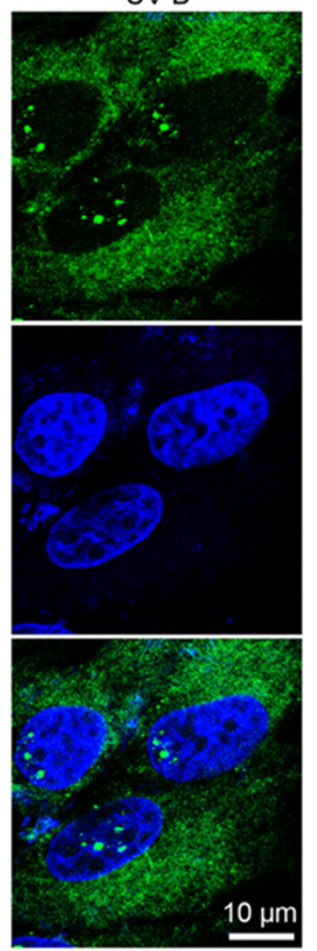

Figure 2. Expression of ADNP in SIRC cells exposed to UV-B radiations. (A) Representative immunoblots of ADNP expression in SIRC cells following exposure to UV-B insult. The bar graph shows quantitative analysis of signals obtained by immunoblots resulting from three independent experiments. Relative band densities were quantified using ImageJ software. Protein levels are expressed as arbitrary units obtained following normalization to b-tubulin, which was used as loading control. Data represent means \pm SEM. ${ }^{* * *} p<0.001$ vs. CTRL, as determined by unpaired two-tailed Student t-test. (B) Representative photomicrographs showing ADNP expression (green) in SIRC cells exposed to UV-B radiations. Nuclei were stained with DAPI. Photomicrographs are representative results of fields taken randomly from each slide and scanned by confocal laser scanning microscopy (CLSM; Zeiss LSM700). In the right column, a thin section $(0.3 \mu \mathrm{m})$ with some SIRC cells showing ADNP in the euchromatic compartment of the nuclei is shown. Scale bar in the left and middle columns is $20 \mu \mathrm{m}$, and in the right column is $10 \mu \mathrm{m}$.

To confirm the protective effect of NAP against UV-B-induced apoptosis, we analyzed the expression of apoptosis-associated proteins such as Bcl-2 and Bax through Western blot analysis. As shown in Figure 5, the treatment with NAP of UV-B-exposed cells significantly enhanced Bcl-2 expression. As expected, the expression levels of Bax were opposite to the $\mathrm{Bcl}-2$ protein. In fact, high levels of this apoptosis-inducing protein were found in SIRC cells following UV-B exposure. The NAP treatment reduced Bax expression, restoring it to control levels (Figure 5).

\subsection{NAP Treatment Reduced ROS Formation Induced by UV-B Irradiation of Corneal Epithelial Cells}

It is well known that the apoptotic event induced by UV-B radiation is mediated by ROS overproduction. To evaluate whether corneal epithelial cell death was related to free radical formation following UV-B insult, we measured ROS levels at different time points in SIRC cells exposed for $30 \mathrm{~s}$ to UV-B irradiation $\left(20 \mathrm{~mJ} / \mathrm{cm}^{2}\right)$ using a DCFDA assay. As shown in Figure 6A, cellular ROS levels significantly increased in a time-dependent manner starting from $30 \mathrm{~s}$ after UV-B irradiation. The treatment with NAP significantly reduced their formation starting from $1 \mathrm{~h}$ after UV-B stress. Considering that the mitochondrial superoxide anion is the major ROS formed under stress conditions and strictly involved in 
apoptotic cell death, we detected its time-dependent formation in cells exposed to UV-B irradiation using the MitoSOX ${ }^{\mathrm{TM}}$ Red fluorescence indicator (Figure 6B). We found that its production was increased starting from $1 \mathrm{~h}$ but preponderant at $6 \mathrm{~h}$ and $24 \mathrm{~h}$ after UV-B irradiation. NAP significantly decreased UV-B-induced mitochondrial ROS generation following $1 \mathrm{~h}$ of treatment.

A

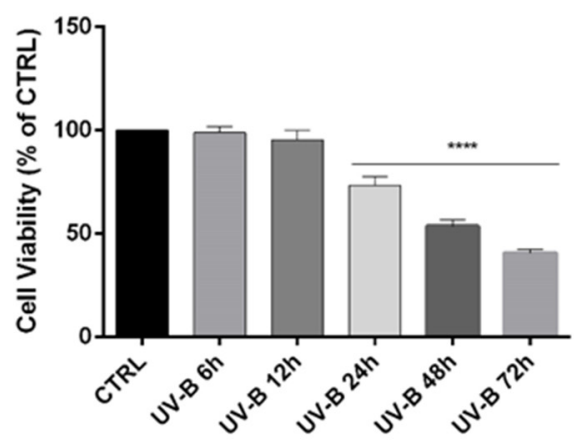

B

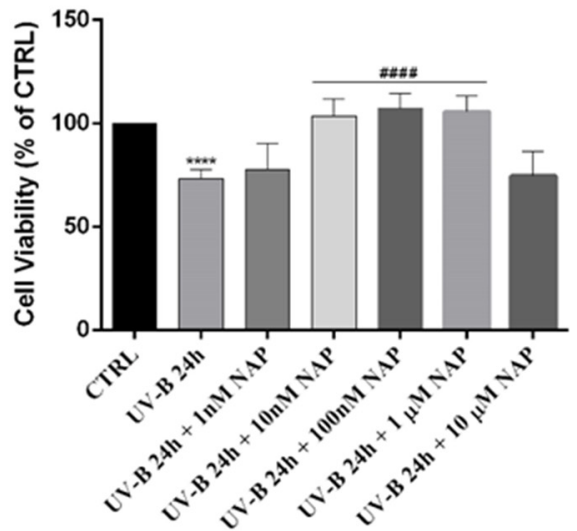

Figure 3. (A) Time-response curve following $30 \mathrm{~s}$ UV-B-irradiation of corneal epithelial cells. (B) Dose-response analysis of SIRC cells viability exposed to $30 \mathrm{~s}$ UV-B irradiation to various NAP concentrations for $24 \mathrm{~h}$. The bar graphs represent mean \pm SEM of three independent experiments and values are expressed as \% of CTRL. ${ }^{* * * *} p<0.0001$ vs. CTRL; \#\#\#\# $p<0.0001$ vs. UV-B 24 h as determined by one-way ANOVA followed by Tukey's multiple comparison test. Twelve replicate wells were used for each group.

CTRL

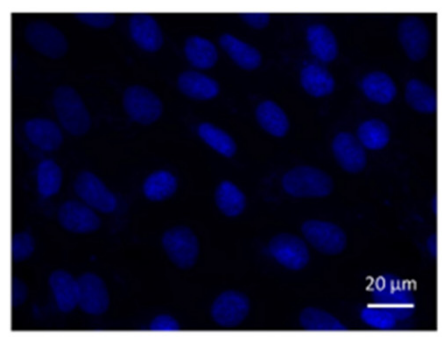

NAP

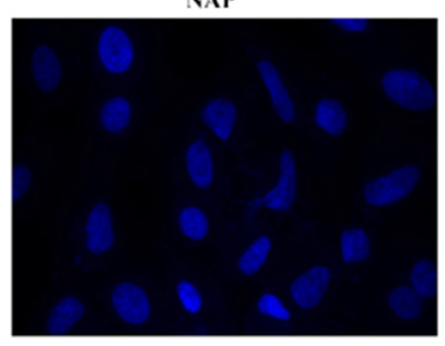

UV-B

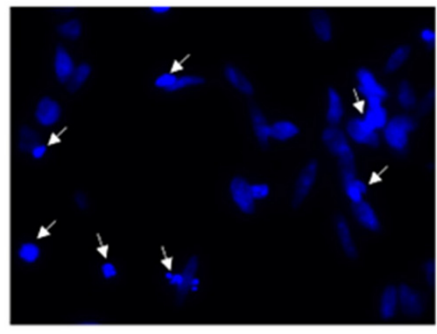

UV-B + NAP

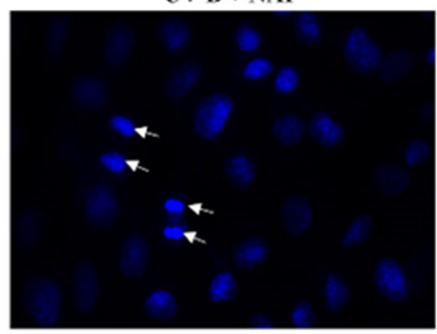

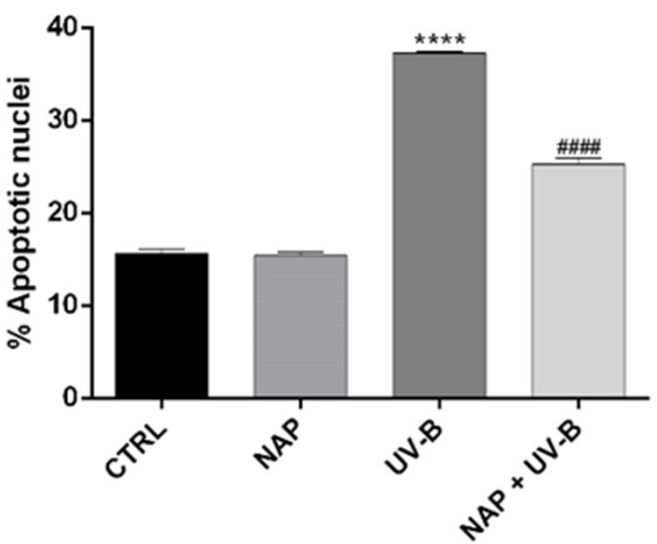

Figure 4. NAP decreased apoptotic cell death induced by UVB-irradiation. SIRC cells were stained with the fluorescent nuclear dye Hoechst 33342 and viewed at $\times 100$ magnification. Nuclei showing the typical features of apoptotic degeneration including chromatin condensation and fragmentation (indicated by white arrows) have been detected by intense blue fluorescence. The bar graph represents mean \pm SEM of apoptotic cells percentages calculated counting cells from seven fields per dish, in a fixed pattern. ${ }^{* * * *} p<0.0001$ vs. CTRL; \#\#\#\# $p<0.0001$ vs. UV-B as determined by one-way ANOVA followed by Tukey's multiple comparison test. Digital micrographs are obtained with an Axiovert 40 fluorescence microscope (Carl Zeiss). 

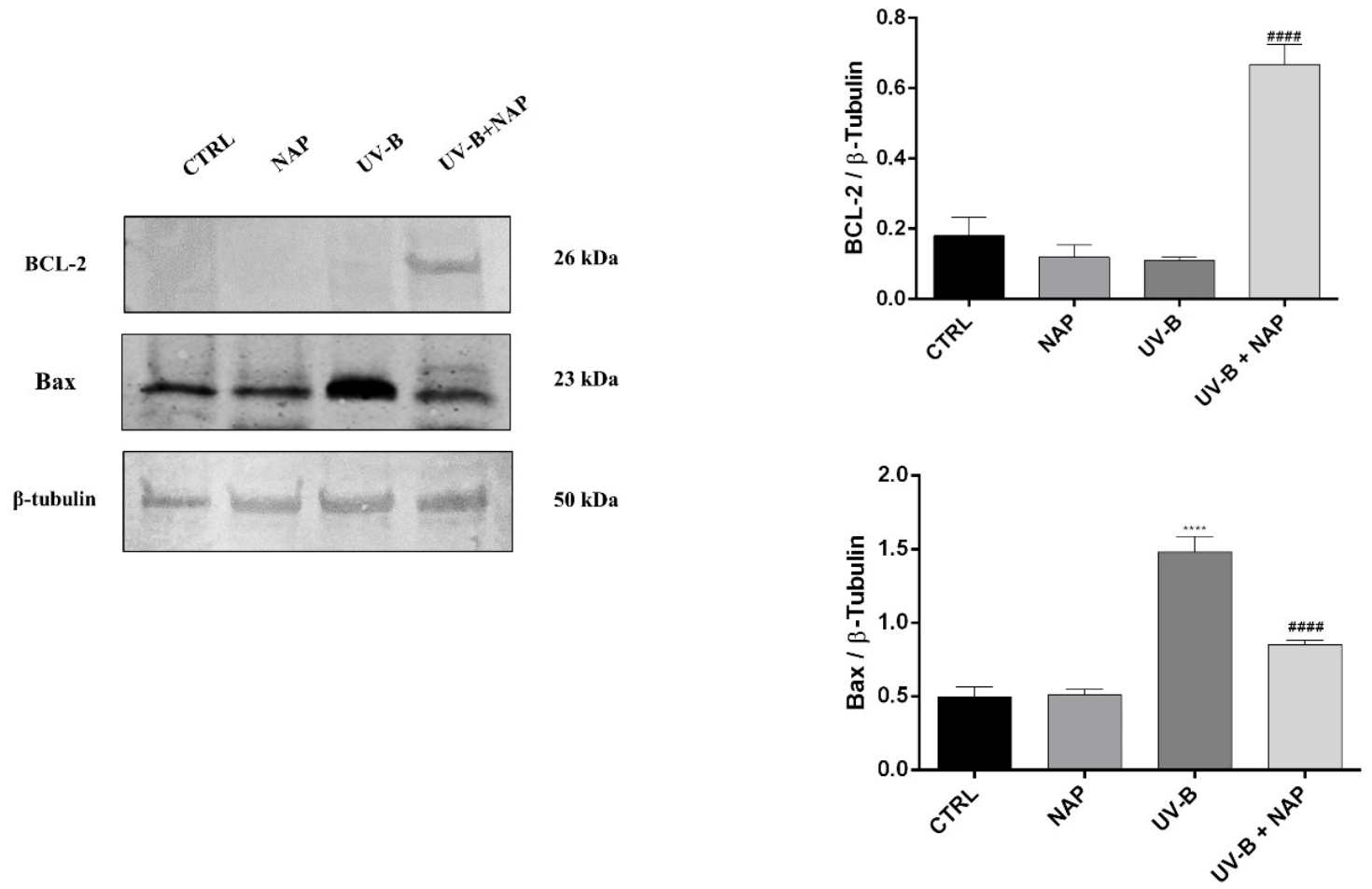

Figure 5. Effect of NAP on Bcl-2/Bax expression of corneal epithelial cells exposed to UV-B rays. Representative immunoblot of Bcl-2 and Bax protein expression in SIRC cells cultured in control medium (CTRL) or treated with $10 \mathrm{nM}$ of NAP, or exposed to UV-B irradiation for $30 \mathrm{~s}$ with or without $10 \mathrm{nM}$ of NAP. The bar graph shows quantitative analysis of signals obtained by immunoblots resulting from three independent experiments. Relative band densities were quantified by using ImageJ software. Protein levels are expressed as arbitrary units obtained after normalization to $\beta$-tubulin, which were used as loading control. Data represent means \pm SEM. ${ }^{* * *} p<0.0001$ vs. CTRL; \#\#\# $p<0.0001$ vs. UV-B as determined by one-way ANOVA followed by Tukey's multiple comparison test.

The c-Jun N-terminal kinases (JNKs), a subfamily of MAPKs, is associated with various cellular stresses by contributing to the induction of apoptosis [42]. In particular, the JNK pathway is activated by oxidative stress induced by UV-B exposure [43]. To investigate whether JNK/MAPK signaling pathway activation was involved in UV-B-ROS-induced cell death, we evaluated the time-course of $\mathrm{p}-\mathrm{JNK} / \mathrm{JNK}$ expression in cells exposed to $30 \mathrm{~s}$ UV-B exposure by performing Western blot analysis. As shown in Figure 7A, a significant increase in p-JNK was observed at $6 \mathrm{~h}$ and $24 \mathrm{~h}$ following UV-B insult $(* * * * p<0.0001$ vs. CTRL). Therefore, we evaluated the effect of NAP on JNK activation after $6 \mathrm{~h}$ UV-B irradiation since, at this time point, a peak of p-JNK expression was observed. On the other hand, NAP treatment significantly reduced JNK activation in the UV-B irradiated group (Figure 7B; \#\#\#\# $p<0.0001$ vs. UV-B). 
A

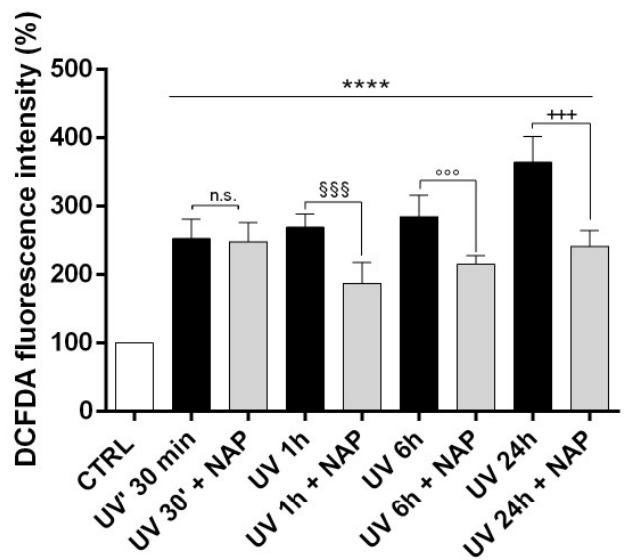

C

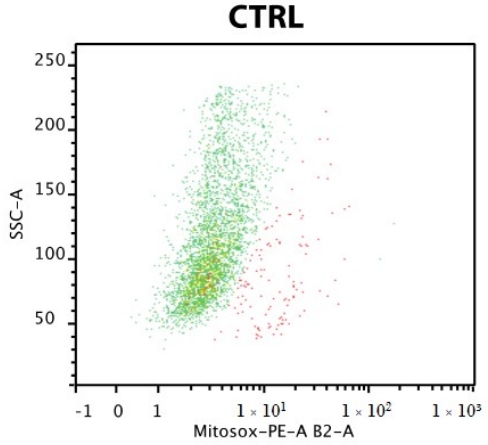

B

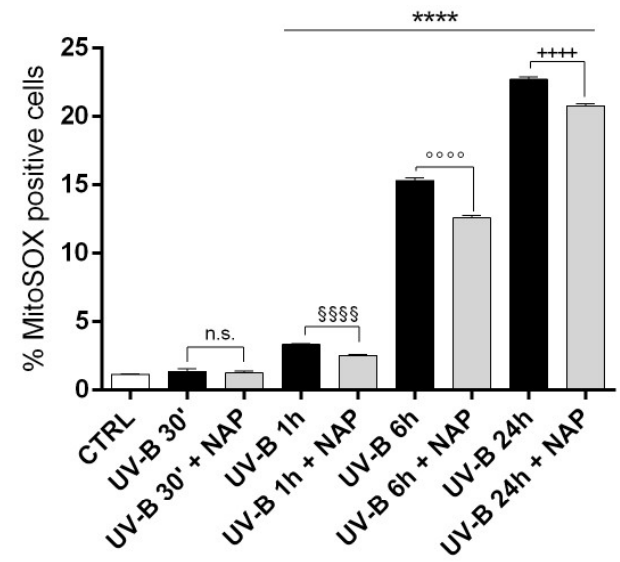

UV

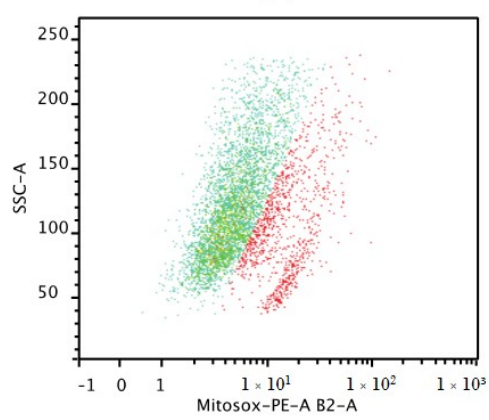

NAP

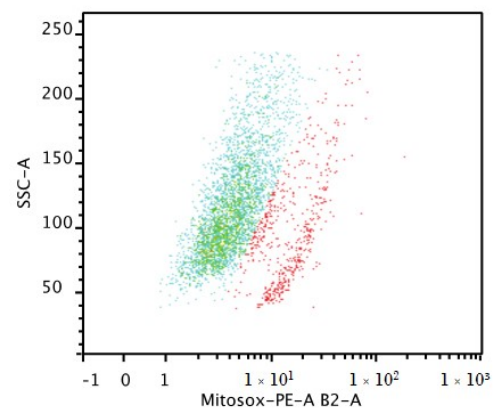

Figure 6. Effect of NAP on UV-B-induced ROS production on corneal epithelial cells. Intracellular ROS levels were measured in SIRC cells at different time intervals after UV-B irradiation using the cytoplasmic probe, DCFDA (A), or the mitochondrial probe, MitoSOX ${ }^{\mathrm{TM}}$ Red (B) at different time points after irradiation with or without NAP treatment. (C) Representative flow cytometry analysis of mitosox Red staining at $6 \mathrm{~h}$. Data are expressed as mean \pm SEM of three independent experiments and values are expressed as \% of MitoSOX ${ }^{\mathrm{TM}}$ Red positive cells. ${ }^{* * *} p<0.0001$ vs. CTRL; $\S \S \S p<0.001$ and $\S \S \S \S p<0.0001$ vs. UV $1 \mathrm{~h} ;{ }^{\circ 00} p<0.001$ and ${ }^{\circ 000} p<0.0001$ vs. UV $6 \mathrm{~h} ;+++p$ $<0.001$ and $++++p<0.0001$ vs. UV $24 \mathrm{~h}$ as determined by one-way ANOVA followed by Tukey's multiple comparison test. 
A

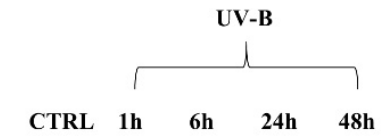

P-JNK

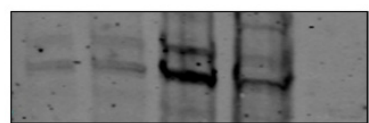

JNK

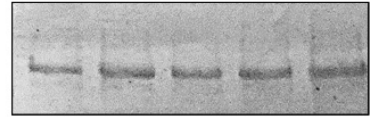

$46 \mathrm{kDa}$

$54 \mathrm{kDa}$

$46 \mathrm{kDa}$

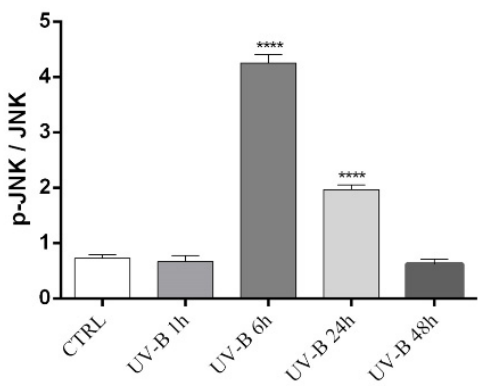

B
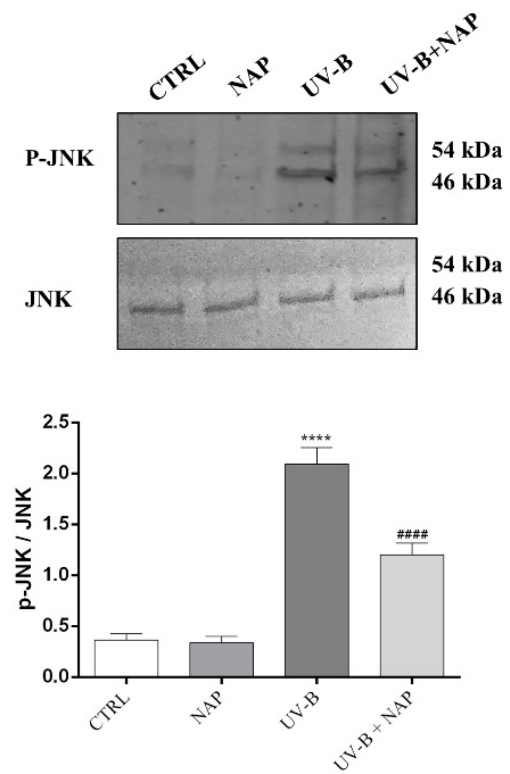

Figure 7. (A) Time-dependent effect of UV-B-induced JNK activation on corneal epithelial cells. The JNK phosphorylation was measured in SIRC cells at different time intervals after UV-B irradiation. (B) NAP treatment prevents UV-B-induced JNK phosphorylation in corneal epithelial cells. Representative immunoblots of JNK phosphorylation expression at $6 \mathrm{~h}$ in SIRC cells cultured in control medium (CTRL) or treated with $10 \mathrm{nM}$ of NAP, or exposed to UV-B irradiation with or without $10 \mathrm{nM}$ of NAP. The bar graphs show quantitative analysis of signals obtained by immunoblots resulting from three independent experiments. Relative band densities were quantified by using ImageJ software. Protein levels are expressed as arbitrary units obtained following normalization to total JNK, which was used as loading control. Data represent means \pm SEM. ${ }^{* * * *} p<0.0001$ vs. CTRL; \#\#\#\# $p<0.0001$ vs. UV-B as determined by one-way ANOVA followed by Tukey's multiple comparison test.

\section{Discussion}

UV light is an environmental agent causing significant ocular damage and inflammation. Sunlight with a wavelength shorter than $295 \mathrm{~nm}$ is absorbed by the ozone layer, whereas UV-B (290-320 nm) and UV-A (320-400 nm) radiations can reach the cornea and lens, respectively. The UV-B-induced corneal injury is due to oxidative stress induced by ROS formation in the corneal epithelial cells $[44,45]$. ROS, including the superoxide anion, hydrogen peroxide, and hydroxyl radicals, cause DNA mutations as well as apoptotic cell death. In particular, a single acute dose of UV-B rays could damage the corneal epithelium, whereas higher doses led to a remarkable decrease in its thickness with a significant reduction of $\mathrm{Na}^{+}-\mathrm{K}^{+}$-dependent adenosine triphosphatase, representing the major transporter involved in the corneal hydration [46-50]. Several papers have demonstrated that NAP, a small fragment derived from the glial cell mediator ADNP, has protective effects in different ocular diseases [23,51,52]. Moreover, in vitro and in vivo studies showed that NAP protected cells against toxicity associated with oxidative stress [22], conferred protection from apoptosis [23], and promoted antioxidant defense by reducing ROS generation [53]. Since ROS formation and apoptotic cell death represent the two central features of UV-B damage [54,55], the main goal of the current study was to evaluate whether ADNP, a peptide constitutively expressed in the corneal epithelium, played a protective role against UV-B insult.

In this work, we showed, for the first time, the presence of ADNP in human and rabbit corneal epitheliums (Figure 1). ADNP-like immunoreactivity was detected in all layers of corneal epithelium of both species, although higher staining intensity was observed in the inner basal layer (Figure 1A,B). The latter is formed by a stem cell monolayer involved in the regeneration of the corneal epithelium [56] as confirmed by p63 immuno- 
positive staining. These data suggested that ADNP might have an important role in corneal regeneration. To investigate its protective role on the corneal epithelium, we performed an in vitro study on SIRC cells exposed to UV-B irradiation. Here, we found high expression levels of the ADNP protein in cells exposed to UV-B rays for $30 \mathrm{~s}$ (Figure 2A). Moreover, immunofluorescence analysis revealed that ADNP was detected not only in the cytoplasm but also in the nucleus by forming small subnuclear bodies (Figure 2B). Various literature data have demonstrated nuclear localization of ADNP $[57,58]$. This protein contains the thiotransferase/glutaredoxin active site [22], which regulates its own and other DNAbinding proteins' expression in response to oxidative stress. Therefore, ADNP translocation from the cytoplasm to the nucleus and vice versa could be involved in the mechanism regulating cell fate in response to UV-B damage.

To investigate whether higher expression of the ADNP protein following the UV-B irradiation is related to its protective role against this insult, we treated irradiated cells with the ADNP-derived small active peptide, NAP, whose structure allows membrane penetration. Many studies demonstrated that this small active element is able to protect cells against the induction of cell death by a variety of stresses [21-27,59]. Here, we demonstrated that NAP treatment prevents UV-B rays-induced damage (Figure $3 \mathrm{~B}$ ) by reducing the percentage of apoptotic cells (Figure 4). To confirm these data, we also evaluated the expression of two proteins: The proapoptotic protein Bax and the antiapoptotic protein Bcl-2, both implicated in the maintenance of tissue homeostasis. Under physiological conditions, their expression is in equilibrium, whereas exposure to different cytotoxic stimuli, such as UV-B radiation, alter this balance leading to apoptotic cell death via an increase in Bax levels. In accord with this evidence, our data indicated that UV-Birradiation results in a significant upregulation of Bax expression (Figure 5). NAP treatment prevented apoptotic death of irradiated cells by increasing Bcl-2 and decreasing BAX levels (Figure 5). These findings were consistent with previous reports describing that NAP displayed anti-apoptotic activity through the downregulation of BAX and upregulation of Bcl-2 expression following exposure to different type of insults such as early diabetic injury or hyperglycemic/hypoxic events $[28,60]$. The UV-B radiations damage is mediated by ROS overproduction, which plays a key role in apoptotic cell death induction [54, 55]. In accord, our results showed that UV-B radiation markedly increased cellular ROS generation as well as mitochondrial superoxide anion formation in a time-dependent manner. NAP treatment exerted a regulatory effect on UV-B-induced oxidative stress by counteracting $\mathrm{ROS}$ overproduction and, in particular, $\mathrm{O}_{2}{ }^{\bullet-}$ formation in the mitochondria (Figure 6A and B).

In corneal epithelial cells exposed to UV-B, the increase in ROS induced apoptotic cell death through the activation of the JNK MAPK pathway. It is well known that ROS formed during UV-B exposure acts as a second messenger by activating the JNK MAPK signal transduction pathway $[59,61]$. The activation of this signaling cascade is directly involved in apoptotic cell death. In fact, it has been previously demonstrated that $\mathrm{p}$ JNK binds to a pro-apoptotic Bcl-2 member, known as Bim, activating Bax-dependent apoptotic machinery during cells' exposure to UV-B [62,63]. Here, we confirmed that UV-B rays trigger JNK phosphorylation, whereas its activation is abrogated by NAP treatment (Figure 7). These results suggested that NAP may counteract UV-B-induced apoptotic cell death by modulating ROS production and antagonizing the JNK MAPK pathway.

The exact step in the UV-B-induced apoptotic cell death regulated by NAP is still unclear. However, we hypothesized that its effect is related to the upstream reduction in ROS formation. It has been previously reported that NAP has antioxidant properties by interfering with various cellular insults $[28,54]$. Therefore, the preferential way travelled by NAP could lead to the reduction of UV-B-induced ROS formation by indirectly inhibiting the JNK/Bax signaling pathway. The mechanism underlying the proposed connections is represented in Figure 8. 


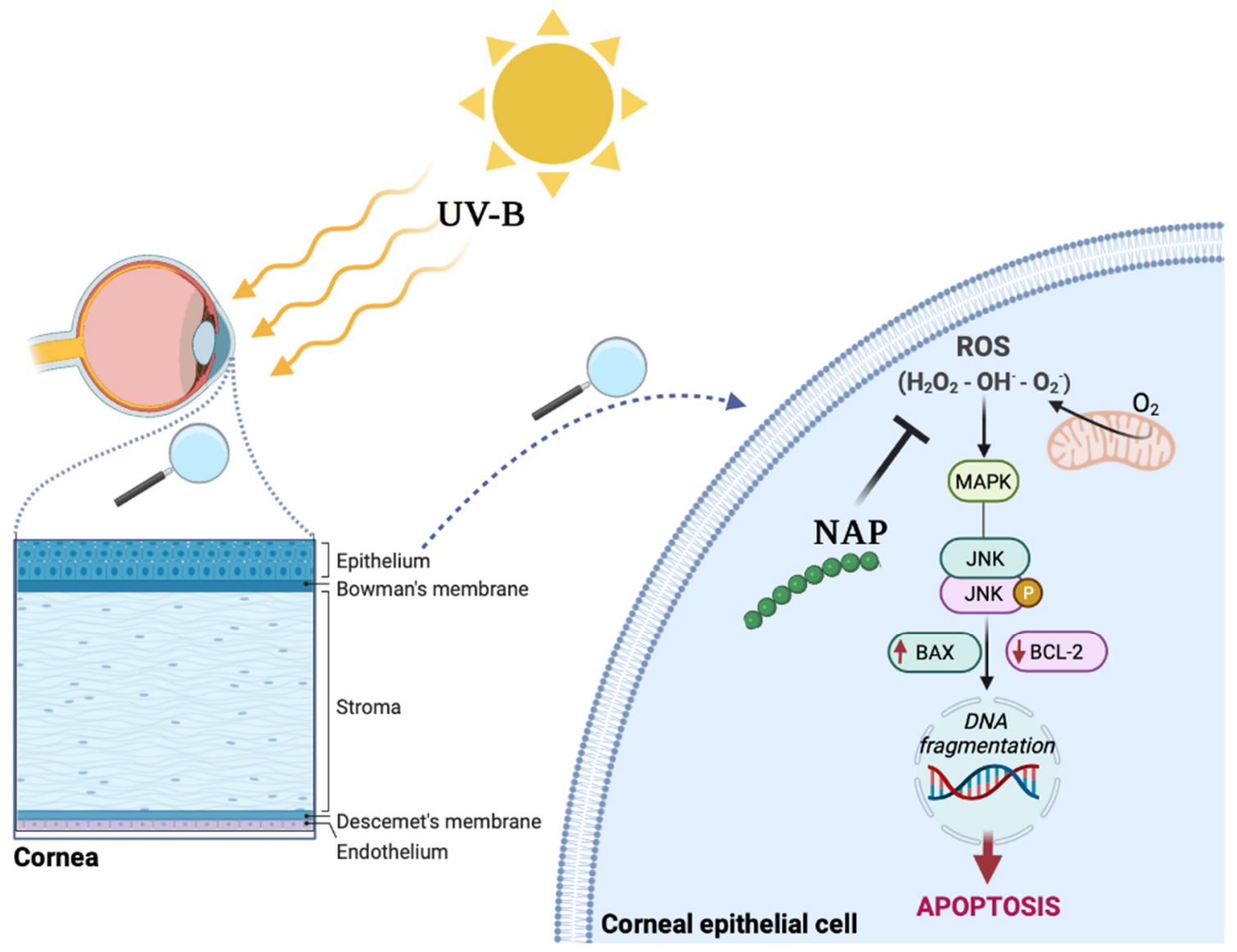

Figure 8. Protective effects of NAP on corneal epithelium exposed to UV-B radiation. Schematic representation of NAP effect on ROS formation, indirectly inducing downregulation of JNK/Bax signaling pathways.

One of the weaknesses of this study is that experiments are performed on the SIRC cell line growing as a single monolayer. This experimental approach does not allow one to simulate all the in vivo properties of the corneal stratified squamous epithelium. Despite this limitation, the data reported in the present paper suggested that NAP might serve as a potential therapeutic agent for corneal epithelial damage attributable to its antioxidant and anti-apoptotic activity. Therefore, this evidence should prompt the scientific community to further investigate NAP effects in the cornea in vivo exhibiting a multi-layered complex architecture.

Author Contributions: All authors reviewed the manuscript. Conceptualization, G.M. (Grazia Maugeri) and V.D.; funding acquisition, G.M. (Grazia Maugeri), S.G., and G.M. (Giuseppe Musumeci); investigation, G.M. (Grazia Maugeri), A.G.D., S.S., C.F., C.G. and D.T.; resources, S.G., C.B., D.S., A.L., and T.A., visualization, C.B.; writing-original draft, G.M. (Grazia Maugeri), A.G.D. and V.D.; writing-review and editing, G.M. (Grazia Maugeri), A.G.D. and V.D. All authors have read and agreed to the published version of the manuscript.

Funding: PIAno di inCEntivi per la RIcerca di Ateneo 2020/2022 Linea di Intervento 3 "Starting Grant" "REPAIR"; Linea Intervento 2 "Nanoret" and Italian Ministry of Education, University and Research (MIUR) (grant number PRIN 2017TSHBXZ_003).

Institutional Review Board Statement: The study was conducted according to the guidelines of the Declaration of Helsinki and approved by the Institution of Animal Care and Use Committee of Catania University (Approval number 303) and the Ethics Committee "Catania 1" (ethical approval number 99/2019/PO). 
Informed Consent Statement: Informed consent was obtained from all subjects involved in the study.

Data Availability Statement: The data presented in this study are available in article.

Acknowledgments: Thanks to Elisabetta Pricoco for technical support.

Conflicts of Interest: The authors declare no conflict of interest.

\section{References}

1. Eagle, R.C. Eye Pathology: An Atlas and Text, 3rd ed.; Lippincott Williams \& Wilkins (LWW): Philadelphia, PA, USA, 2016.

2. Dua, H.S.; Shanmuganathan, V.A.; Powell-Richards, A.O.; Tighe, P.J.; Joseph, A. Limbal epithelial crypts: A novel anatomical structure and a putative limbal stem cell niche. Br. J. Ophthalmol. 2005, 89, 529-532. [CrossRef]

3. Downes, J.E.; Swann, P.G.; Holmes, R.S. Differential corneal sensitivity to ultraviolet light among inbred strains of mice. Correlation of ultraviolet B sensitivity with aldehyde dehydrogenase deficiency. Cornea 1994, 13, 67-72. [CrossRef] [PubMed]

4. Kolozsvári, L.; Nógrádi, A.; Hopp, B.; Bor, Z. UV absorbance of the human cornea in the 240- to 400-nm range. Investig. Ophthalmol. Vis. Sci. 2002, 43, 2165-2168. [PubMed]

5. Cullen, A.P. Photokeratitis and other phototoxic effects on the cornea and conjunctiva. Int. J. Toxicol. 2002, 21, 455-464. [CrossRef]

6. Glupker, C.D.; Boersma, P.M.; Schotanus, M.P.; Haarsma, L.D.; Ubels, J.L. Apoptosis of Corneal Epithelial Cells Caused by Ultraviolet B-induced Loss of $\mathrm{K}(+)$ is Inhibited by Ba(2.). Ocul. Surf. 2016, 14, 401-409. [CrossRef]

7. McCubrey, J.A.; Lahair, M.M.; Franklin, R.A. Reactive oxygen species-induced activation of the MAP kinase signaling pathways. Antioxid. Redox Signal. 2006, 8, 1775-1789. [CrossRef] [PubMed]

8. Maugeri, G.; D’Amico, A.G.; Amenta, A.; Saccone, S.; Federico, C.; Reibaldi, M.; Russo, A.; Bonfiglio, V.; Avitabile, T.; Longo, A.; et al. Protective effect of PACAP against ultraviolet B radiation-induced human corneal endothelial cell injury. Neuropeptides 2020, 79, 101978. [CrossRef] [PubMed]

9. Vaudry, D.; Falluel-Morel, A.; Bourgault, S.; Basille, M.; Burel, D.; Wurtz, O.; Fournier, A.; Chow, B.K.; Hashimoto, H.; Galas, L.; et al. Pituitary adenylate cyclase-activating polypeptide and its receptors: 20 years after the discovery. Pharmacol. Rev. 2009, 61, 283-357. [CrossRef]

10. Toth, D.; Szabo, E.; Tamas, A.; Juhasz, T.; Horvath, G.; Fabian, E.; Opper, B.; Szabo, D.; Maugeri, G.; D'Amico, A.G.; et al. Protective Effects of PACAP in Peripheral Organs. Front. Endocrinol. (Lausanne) 2020, 11, 377. [CrossRef]

11. Harmar, A.J.; Fahrenkrug, J.; Gozes, I.; Laburthe, M.; May, V.; Pisegna, J.R.; Vaudry, D.; Vaudry, H.; Waschek, J.A.; Said, S.I. Pharmacology and functions of receptors for vasoactive intestinal peptide and pituitary adenylate cyclase-activating polypeptide: IUPHAR review 1. Br. J. Pharmacol. 2012, 166, 4-17. [CrossRef]

12. Dejda, A.; Jolivel, V.; Bourgault, S.; Seaborn, T.; Fournier, A.; Vaudry, H.; Vaudry, D. Inhibitory effect of PACAP on caspase activity in neuronal apoptosis: A better understanding towards therapeutic applications in neurodegenerative diseases. J. Mol. Neurosci. 2008, 36, 26-37. [CrossRef]

13. Canonico, P.L.; Copani, A.; D'Agata, V.; Musco, S.; Petralia, S.; Travali, S.; Stivala, F.; Cavallaro, S. Activation of pituitary adenylate cyclase-activating polypeptide receptors prevents apoptotic cell death in cultured cerebellar granule cells. Ann. N.Y. Acad. Sci. 1996, 26, 470-472. [CrossRef]

14. Maugeri, G.; Longo, A.; D’Amico, A.G.; Rasà, D.M.; Reibaldi, M.; Russo, A.; Bonfiglio, V.; Avitabile, T.; D’Agata, V. Trophic effect of PACAP on human corneal endothelium. Peptides 2018, 99, 20-26. [CrossRef]

15. Reglodi, D.; Kiss, P.; Lubics, A.; Tamas, A. Review on the protective effects of PACAP in models of neurodegenerative diseases in vitro and in vivo. Curr. Pharm. Des. 2011, 17, 962-972. [CrossRef] [PubMed]

16. Waschek, J.A. VIP and PACAP: Neuropeptide modulators of CNS inflammation, injury, and repair. Br. J. Pharmacol. 2013, 69, 512-523. [CrossRef] [PubMed]

17. Maugeri, G.; D’Amico, A.G.; Rasà, D.M.; Federico, C.; Saccone, S.; Morello, G.; La Cognata, V.; Cavallaro, S.; D'Agata, V. Molecular mechanisms involved in the protective effect of pituitary adenylate cyclase-activating polypeptide in an in vitro model of amyotrophic lateral sclerosis. J. Cell. Physiol. 2019, 234, 5203-5214. [CrossRef] [PubMed]

18. Maugeri, G.; D’Amico, A.G.; Morello, G.; Reglodi, D.; Cavallaro, S.; D’Agata, V. Differential Vulnerability of Oculomotor versus Hypoglossal Nucleus during ALS: Involvement of PACAP. Front. Neurosci. 2020, 14, 805. [CrossRef]

19. Maugeri, G.; D'Amico, A.G.; Musumeci, G.; Reglodi, D.; D'Agata, V. Effects of Pacap on Schwann Cells: Focus on Nerve Injury. Int. J. Mol. Sci. 2020, 21, 8233. [CrossRef]

20. D’Amico, A.G.; Maugeri, G.; Saccone, S.; Federico, C.; Cavallaro, S.; Reglodi, D.; D'Agata, V. PACAP Modulates the Autophagy Process in an in Vitro Model of Amyotrophic Lateral Sclerosis. Int. J. Mol. Sci. 2020, 21, 2943. [CrossRef]

21. Bassan, M.; Zamostiano, R.; Davidson, A.; Pinhasov, A.; Giladi, E.; Perl, O.; Bassan, H.; Blat, C.; Gibney, G.; Glazner, G.; et al. Complete sequence of a novel protein containing a femtomolar-activity-dependent neuroprotective peptide. J. Neurochem. 1999, 72, 1283-1293. [CrossRef] [PubMed]

22. Zamostiano, R.; Pinhasov, A.; Gelber, E.; Steingart, R.A.; Seroussi, E.; Giladi, E.; Bassan, M.; Wollman, Y.; Eyre, H.J.; Mulley, J.C.; et al. Cloning and characterization of the human activity-dependent neuroprotective protein. J. Biol. Chem. 2001, 276, 708-714. [CrossRef] 
23. Leker, R.R.; Teichner, A.; Grigoriadis, N.; Ovadia, H.; Brenneman, D.E.; Fridkin, M.; Giladi, E.; Romano, J.; Gozes, I. NAP, a femtomolar-acting peptide, protects the brain against ischemic injury by reducing apoptotic death. Stroke 2002, 33, 1085-1092. [CrossRef] [PubMed]

24. Beni-Adani, L.; Gozes, I.; Cohen, Y.; Assaf, Y.; Steingart, R.A.; Brenneman, D.E.; Eizenberg, O.; Trembolver, V.; Shohami, E. A peptide derived from activity-dependent neuroprotective protein (ADNP) ameliorates injury response in closed head injury in mice. J. Pharmacol. Exp. Ther. 2001, 296, 57-63.

25. Gozes, I.; Steingart, R.A.; Spier, A.D. NAP mechanisms of neuroprotection. J. Mol. Neurosci. 2004, 24, 67-72. [CrossRef]

26. Idan-Feldman, A.; Schirer, Y.; Polyzoidou, E.; Touloumi, O.; Lagoudaki, R.; Grigoriadis, N.C.; Gozes, I. Davunetide (NAP) as a preventative treatment for central nervous system complications in a diabetes rat model. Neurobiol. Dis. 2011, 44, 327-339. [CrossRef]

27. D'Amico, A.G.; Maugeri, G.; Bucolo, C.; Saccone, S.; Federico, C.; Cavallaro, S.; D'Agata, V. Nap Interferes with Hypoxia-Inducible Factors and VEGF Expression in Retina of Diabetic Rats. J. Mol. Neurosci. 2017, 61, 256-266. [CrossRef] [PubMed]

28. D'Amico, A.G.; Maugeri, G.; Rasà, D.M.; La Cognata, V.; Saccone, S.; Federico, C.; Cavallaro, S.; D'Agata, V. NAP counteracts hyperglycemia/hypoxia induced retinal pigment epithelial barrier breakdown through modulation of HIFs and VEGF expression. J. Cell. Physiol. 2018, 233, 1120-1128. [CrossRef]

29. D'Amico, A.G.; Maugeri, G.; Rasà, D.; Federico, C.; Saccone, S.; Lazzara, F.; Fidilio, A.; Drago, F.; Bucolo, C.; D’Agata, V. NAP modulates hyperglycemic-inflammatory event of diabetic retina by counteracting outer blood retinal barrier damage. J. Cell. Physiol. 2019, 234, 5230-5240. [CrossRef]

30. Zheng, H.; Blat, D.; Fridkin, M. Novel neuroprotective neurotrophic NAP analogs targeting metal toxicity and oxidative stress: Potential candidates for the control of neurodegenerative diseases. J. Neural Transm. Suppl. 2006, 71, 163-172.

31. Sethy, N.K.; Sharma, N.K.; Das, M.; Bhargava, K. Protein profiling reveals antioxidant and signaling activities of NAP (Davunetide) in rodent hippocampus exposed to hypobaric hypoxia. J. Mol. Neurosci. 2014, 54, 414-429. [CrossRef]

32. Escher, U.; Giladi, E.; Dunay, I.R.; Bereswill, S.; Gozes, I.; Heimesaat, M.M. Anti-inflammatory Effects of the Octapeptide NAP in Human Microbiota-Associated Mice Suffering from Subacute Ileitis. Eur. J. Microbiol. Immunol. (Bp) 2018, 8, 34-40. [CrossRef] [PubMed]

33. Maugeri, G.; D'Amico, A.G.; Castrogiovanni, P.; Saccone, S.; Federico, C.; Reibaldi, M.; Russo, A.; Bonfiglio, V.; Avitabile, T.; Longo, A.; et al. PACAP through EGFR transactivation preserves human corneal endothelial integrity. J. Cell. Biochem. 2019, 120, 10097-10105. [CrossRef]

34. Maugeri, G.; D’Amico, A.G.; Rasà, D.M.; Saccone, S.; Federico, C.; Cavallaro, S.; D'Agata, V. PACAP and VIP regulate hypoxiainducible factors in neuroblastoma cells exposed to hypoxia. Neuropeptides 2018, 69, 84-91. [CrossRef] [PubMed]

35. Maugeri, G.; D'Amico, A.G.; Rasà, D.M.; Saccone, S.; Federico, C.; Magro, G.; Cavallaro, S.; D'Agata, V. Caffeine Effect on HIFs/VEGF Pathway in Human Glioblastoma Cells Exposed to Hypoxia. Anti-Cancer Agents Med. Chem. 2018, 18, 1432-1439. [CrossRef] [PubMed]

36. Maugeri, G.; D’Amico, A.G.; Rasà, D.M.; La Cognata, V.; Saccone, S.; Federico, C.; Cavallaro, S.; D’ Agata, V. Nicotine promotes blood retinal barrier damage in a model of human diabetic macular edema. Toxicol. In Vitro 2017, 44, 182-189. [CrossRef]

37. Maugeri, G.; D'Amico, A.G.; Rasà, D.M.; Reitano, R.; Saccone, S.; Federico, C.; Parenti, R.; Magro, G.; D'Agata, V. Expression profile of Wilms Tumor 1 (WT1) isoforms in undifferentiated and all-trans retinoic acid differentiated neuroblastoma cells. Genes Cancer 2016, 7, 47-58. [CrossRef]

38. Schlötzer-Schrehardt, U.; Kruse, F.E. Identification and characterization of limbal stem cells. Exp. Eye Res. 2005, 81, 247-264 [CrossRef]

39. Mandel, S.; Spivak-Pohis, I.; Gozes, I. ADNP Differential Nucleus/Cytoplasm Localization in Neurons Suggests Multiple Roles in Neuronal Differentiation and Maintenance. J. Mol. Neurosci. 2008, 35, 127-141. [CrossRef]

40. Cullen, A.P.; Chou, B.R.; Hall, M.G.; Jany, S.E. Ultraviolet-B damages corneal endothelium. Am. J. Optom. Physiol. Opt. 1984, 61, 473-478. [CrossRef]

41. Suzuki, Y.; Ohgami, K.; Shiratori, K.; Jin, X.H.; Ilieva, I.; Koyama, Y.; Yazawa, K.; Yoshida, K.; Kase, S.; Ohno, S. Suppressive effects of astaxanthin against rat endotoxin-induced uveitis by inhibiting the NF-kappaB signaling pathway. Exp. Eye Res. 2006, 82, 275-281. [CrossRef]

42. Wada, T.; Penninger, J. Mitogen-activated protein kinases in apoptosis regulation. Oncogene 2004, 23, 2838-2849. [CrossRef]

43. Shen, H.M.; Liu, Z.G. JNK signaling pathway is a key modulator in cell death mediated by reactive oxygen and nitrogen species. Free Radic. Biol. Med. 2006, 40, 928-939. [CrossRef]

44. Cejkova, J.; Stipek, S.; Crkovska, J.; Ardan, T.; Midelfart, A. Reactive oxygen species (ROS)-generating oxidases in the normal rabbit cornea and their involvement in the corneal damage evoked by UVB rays. Histo. Histopath. 2001, 16, 523-533.

45. Cejkova, J.; Stipek, S.; Crkovska, J.; Ardan, T.; Platenik, J.; Cejka, C.; Midelfart, A. UV rays, the prooxidant/antioxidant imbalance in the cornea and oxidative eye damage. Physiol. Rev. 2004, 53, 1-10.

46. Shoham, A.; Hadziahmetovic, M.; Dunaief, J.L.; Mydlarski, M.B.; Schipper, H.M. Oxidative stress in diseases of the human cornea. Free Radic. Biol. Med. 2008, 45, 1047-1055. [CrossRef] [PubMed]

47. Shimmura, S.; Suematsu, M.; Shimoyama, M.; Tsubota, K.; Oguchi, Y.; Ishimura, Y. Subthreshold UV radiation-induced peroxide formation in cultured corneal epithelial cells: The protective effects of lactoferrin. Exp. Eye Res. 1996, 63, 519-526. [CrossRef] 
48. Cullen, A.P. Ultraviolet induced lysosome activity in corneal epithelium. Albrecht Von Graefes Arch. Klin. Exp. Ophthalmol. 1980, 214, 107-118. [CrossRef]

49. Koliopoulos, J.X.; Margaritis, L.H. Response of the cornea to far ultraviolet light: An ultrastructural study. Ann. Ophthalmol. 1979, $11,765-769$.

50. Redmond, T.M.; Duke, E.J.; Coles, W.H.; Simson, J.A.; Crouch, R.K. Localization of corneal superoxide dismutase by biochemical and histocytochemical techniques. Exp. Eye Res. 1984, 38, 369-378. [CrossRef]

51. Jehle, T.; Dimitriu, C.; Auer, S.; Knoth, R.; Vidal-Sanz, M.; Gozes, I.; Lagrze, W.A. The neuropeptide NAP provides neuroprotection against retinal ganglion cell damage after retinal ischemia and optic nerve crush. Graefes Arch. Clin. Exp. Ophthalmol. 2008, 246, 1255-1263. [CrossRef]

52. Zheng, Y.; Zeng, H.; She, H.; Liu, H.; Sun, N. Expression of peptide NAP in rat retinal Müller cells prevents hypoxia-induced retinal injuries and promotes retinal neurons growth. Biomed. Pharmacother. 2010, 64, 417-423. [CrossRef]

53. Arya, A.; Meena, R.; Sethy, N.K.; Das, M.; Sharma, M.; Bhargava, K. NAP (davunetide) protects primary hippocampus culture by modulating expression profile of antioxidant genes during limiting oxygen conditions. Free Radic. Res. 2015, 49, 440-452. [CrossRef] [PubMed]

54. Matsuzawa, A.; Ichijo, H. Stress-responsive protein kinases in redox-regulated apoptosis signaling. Antioxid. Redox Signal. 2005, 7, 472-481. [CrossRef] [PubMed]

55. Chiu, W.H.; Luo, S.J.; Chen, C.L.; Cheng, J.H.; Hsieh, C.Y.; Wang, C.Y.; Huang, W.C.; Su, W.C.; Lin, C.F. Vinca alkaloids cause aberrant ROS-mediated JNK activation, Mcl-1 downregulation, DNA damage, mitochondrial dysfunction, and apoptosis in lung adenocarcinoma cells. Biochem. Pharmacol. 2012, 83, 1159-1171. [CrossRef]

56. Tseng, S.C.G. Concept and application of limbal stem cells. Eye 1989, 3, 141-157. [CrossRef]

57. Cappuyns, E.; Huyghebaert, J.; Vandeweyer, G.; Kooy, R.F. Mutations in ADNP affect expression and subcellular localization of the protein. Cell Cycle 2018, 17, 1068-1075. [CrossRef]

58. Belokopytov, M.; Shulman, S.; Dubinsky, G.; Gozes, I.; Belkin, M.; Rosner, M. Ameliorative effect of NAP on laser-induced retinal damage. Acta Ophthalmol. 2011, 89, e126-e131. [CrossRef]

59. Jeon, S.H.; Park, H.M.; Kim, S.J.; Lee, M.Y.; Kim, G.B.; Rahman, M.M.; Woo, J.N.; Kim, I.S.; Kim, J.S.; Kang, H.S. Taurine reduces FK506-induced generation of ROS and activation of JNK and Bax in Madin Darby canine kidney cells. Hum. Exp. Toxicol. 2010, 29, 627-633. [CrossRef]

60. Scuderi, S.; D'Amico, A.G.; Castorina, A.; Federico, C.; Marrazzo, G.; Drago, F.; Bucolo, C.; D'Agata, V. Davunetide (NAP) protects the retina against early diabetic injury by reducing apoptotic death. J. Mol. Neurosci. 2014, 54, 395-404. [CrossRef]

61. Park, G.B.; Choi, Y.; Kim, Y.S.; Lee, H.K.; Kim, D.; Hur, D.Y. ROS-mediated JNK/p38-MAPK activation regulates Bax translocation in Sorafenib-induced apoptosis of EBV-transformed B cells. Int. J. Oncol. 2014, 44, 977-985. [CrossRef] [PubMed]

62. Dhanasekaran, D.N.; Reddy, E.P. JNK signaling in apoptosis. Oncogene 2008, 27, 6245-6251. [CrossRef] [PubMed]

63. Jia, Y.; Qin, Q.; Fang, C.P.; Shen, W.; Sun, T.T.; Huang, Y.L.; Li, W.J.; Deng, A.M. UVB induces apoptosis via downregulation of CALML3-dependent JNK1/2 and ERK1/2 pathways in cataract. Int. J. Mol. Med. 2018, 41, 3041-3050. [CrossRef] [PubMed] 